Piotr FLIN

Instytut Fizyki, Uniwersytet Jana Kochanowskiego, Kielce, Polska

sfflin@cyf-kr.edu.pl

Elena PANKO

Mikołajowski Uniwersytet Narodowy im. Wasyla Suchomłynskiego, Ukraina

panko.elena@gmail.com

\title{
STOPNIE NAUKOWE W CARSKIEJ ROSJI
}

\begin{abstract}
Streszczenie
Wielu polskich uczonych uzyskiwało stopnie naukowe w uniwersytetach carskiej Rosji. W związku z powyższym pozwalamy sobie na przypomnienie akademickiej hierarchii w carskiej Rosji, które przydać się może osobom zainteresowanym historią nauki.

Słowa kluczowe: stopnie naukowe, hierarchia stopni: student, kandydat nauk uniwersytetu, magister, doktor nauk

\section{Wstęp}

Uczeni polscy niejednokrotnie uzyskiwali stopnie naukowe w uniwersytetach carskiej Rosji. Także i Uniwersytet Warszawski zorganizowany był na rosyjskich zasadach. Uniwersytety działały zgodnie z ukazem cara Aleksandra I z dnia 24 stycznia 1803 roku „o utworzeniu okręgów szkolnych”. Bardzo ważnym stwierdzeniem, zawartym w tym dokumencie był zapis, że „nikt nie może być profesorem, nie będąc wcześniej doktorem i adiunktem, nie mając umiejętności magistra, oprócz Rosjan i cudzoziemców, znanych w świecie nauki”. Podkreślono więc ważność uzyskania stopni w hierarchii pedagogicznej. Prawo nadawania stopni uzyskały cztery uniwersytety: moskiewski, dorpacki (juriewski, tartuski), kazański i charkowski, a zaraz potem Uniwersytet Wileński. W 1804 roku powstały statuty tych czterech uczelni, w których dokładnie opisano tryb ich uzyskiwania.
\end{abstract}

\section{Stopnie}

Następnie prawa nadawania stopni naukowych otrzymały uniwersytety w: Warszawie, Kijowie i Sankt Petersburgu. 20 stycznia 1819 roku carski ukaz „Ustawa o stopniach uczonych", a potem rozporządzenia departamentu oświaty zunifikowały system stopni naukowych i wymogi konieczne do ich uzyskania.

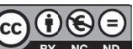


Schemat stopni był następujący: student - kandydat - magister - doktor, co odpowiadało klasie 8, 9, 10 i 12 tabeli rangi urzędników.

Ustawa z 1804 roku rozpoczęła proces usystematyzowania stopni i tytułów naukowych w Rosji, i miała związek z wcześniejszymi zmianami w imperatorskich uniwersytetach w Moskwie, Charkowie i Kazaniu. Część IX ustawy nosiła tytuł «O6 испытаниях и производстве в университетские достоинства» («O próbach i pracach w kierunku usystematyzowania wartości uniwersyteckich»).

1819 roku weszła w życie ustawa o stopniach naukowych, obowiązująca wszystkie uniwersytety w Rosji. Ustanowiono wówczas jeden obowiązujący regulamin, i określono cztery dziedziny nauki, w których można nadawać stopnie: teologię, prawo, medycynę i filozofię. W następnych latach (1837, 1844 i 1864) doprecyzowano przedmioty i nomenklaturę. Obowiązywał schemat: student - kandydat - magister - doktor, a prawo nadawania takich tytułów otrzymały wydziały uniwersytetów.

Ten schemat był oczywiście ściśle związany z obowiązującym w carskiej Rosji systemem rang urzędniczych. W miarę rozwoju uniwersytetów Rosja została podzielona na 8 okręgów naukowych, które zajmowały się edukacją. Ustalono też hierarchię uczelnianą: profesor, profesor nadzwyczajny, docent, priwat-docent, lektor, asystent, laborant. Wszyscy wyżej wymienieni z wyjątkiem priwat-docenta byli pracownikami administracji państwowej, przez nią opłacanymi i posiadającymi odpowiednią do kwalifikacji rangę urzędniczą.

W zasadzie na stanowisko profesora powołany mógł być tylko doktor właściwej dyscypliny, zaś awans na docenta wymagał posiadania stopnia magistra tej dziedziny wiedzy. W przeciwieństwie do pozostałych - priwat-docent nie był pracownikiem państwowym, nie był też wymieniony w tablicy rang. Aby uzyskać to stanowisko, należało wygłosić przed radą wydziału wykład lub wykłady pokazowe i przedstawić dysertację. Stanowisko to związane było z konkretną uczelnią i przechodząc do innej należało się o nie starać od nowa, według przepisów obowiązujących w danym uniwersytecie. ${ }^{1}$

W 1835 roku ustalono terminologię i strukturę uczelnianą: profesor (używano też przymiotnika: zwyczajny, pełny lub państwowy), profesor nadzwyczajny, docent, lektor, asystent, laborant. Po 1863 roku zmiana ustawy utożsamiła stanowiska profesora nadzwyczajnego i docenta. Od roku 1835 do zajmowania stanowiska profesora wymagany był stopień doktora nauk, zaś na stanowisko docenta - magisterium.

Stopień kandydata lub kandydata uniwersytetu - co w pełnym brzmieniu zapisywano jako: kandydat nauk określonej dyscypliny naukowej, określonego uniwersytetu, np. kandydat nauk matematyczno-fizycznych Uniwersytetu Warszawskiego. Stopień ten przysługiwał studentom, którzy osiągnęli bardzo dobre wyniki w nauce i przedstawili dodatkowo pisemną dysertację w ciągu 6 miesięcy od ukończenia studiów (Ryc.1).

1 Zmiany zachodzące w systemie organizacji uniwersytetów w Rosji zostały opisane w: Schiller 2008, gdzie dokładnie przedyskutowano również ich przyczyny. 


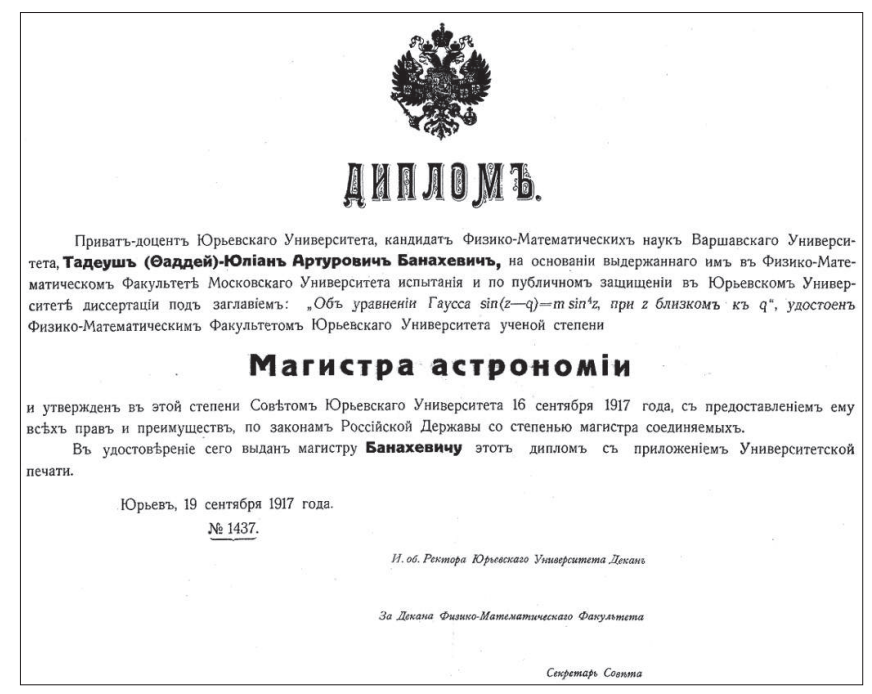

Ryc. 1. Kopia dyplomu magisterskiego (doktorskiego) Tadeusza Banachiewicza (๔ Archiwum Tadeusza Banachiewicza)

W zasadzie stopień ten został zniesiony w 1884 roku i był stosowany tylko w uniwersytetach: warszawskim i juriewskim (tartuskim, dorpackim). Egzamin dyplomowy obejmował jedną z wybranych dyscyplin. Studenci, którzy nie przedstawiali specjalnej rozprawy kończyli studia $\mathrm{z}$ tytułem: rzeczywisty student (действительный студент). Można było uzyskać tytuł kandydata zdając egzaminy i przedstawiając rozprawę, przynajmniej rok po ukończeniu studiów. Tak więc tytuł kandydata był w zasadzie odpowiednikiem dyplomu z wyróżnieniem.

Stopień magistra przyznawano po zdaniu ustnych i pisemnych egzaminów. Dysertacja mogła być specjalnie napisaną pracą albo można było przedstawić opublikowaną już rozprawę. Przygotowanie się do uzyskania stopnia magistra zajmowało około 4 lat. Pytania dla magistranta były liczne, czasem było ich nawet kilkaset. Wymagano wiedzy historycznej z zakresu tematyki magisterium. Stopień magistra był równoważny $\mathrm{PhD}$, czyli doktoratowi w Europie Zachodniej. Natomiast zachodnioeuropejskie doktoraty były traktowane jako stopień magistra po procedurze nostryfikacyjnej w uniwersytecie. Bez niej osoby posiadające nawet doktorat zachodni nie były traktowane jako pełnoprawni doktorzy. (Kolega Tadeusza Banachiewicza z Warszawy, astronom obserwator Eryk Schoenberg (1882-1965), mimo posiada stopnia doktorskiego z Kiel Universität (Kilonia, Niemcy) w Juriewie był traktowany jako posiadający dyplom kandydata Uniwersytetu Warszawskiego. Tak jak Banachiewicz, i prawie równocześnie z nim, po przedstawieniu rozprawy uzyskał tytuł magistra.)

Stopień doktora odpowiadał habilitacji. I podobne też były wymagania: opublikowana praca, publiczny wykład, przygotowanie się do odpowiedzi na liczne pytania oraz krytyczna wiedza w zakresie przedmiotu. 


\title{
3. Podsumowanie
}

Struktura akademicka w Cesarstwie Rosyjskim była podobna do obowiązującej w innych krajach Europy. Zasadnicza różnica polegała na tym, że hierarchia naukowa miała swoje odbicie w tabeli rosyjskich rang urzędniczych. Po wielu próbach w Rosji ukształtował się system nadawania stopni w kolejności: rzeczywisty student - kandydat uniwersytetu - magister - doktor (действительный студент - кандидат университета магистр - доктор), a istotną kwestią stało się urzeczywistnianie zasady: kto uprawia naukę, ten uczy.

\section{Podziękowanie}

Autorzy dziękują P.T. Recenzentom za ich uwagi, przyczyniające się do lepszej prezentacji treści tej pracy.

\section{BIBLIOGRAFIA}

FLIN Piotr, PANKO Elena

2011: Tadeusz Banachiewicz in Tartu (1915 to 1918). Baltic Astronomy 20, pp. 305-309.

2012: Tadeusz Banachiewicz w Kazaniu (1910-1915) i Tartu (1915-1918). Częstochowski Kalendarz Astronomiczny, ss. 145-149.

SCHILLER Joanna

2008: Universitas rossica. Koncepcja uniwersytetu rosyjskiego 1863-1917. Warszawa: Wydawnictwo IHN PAN i Wydawnictwo Retro-Ars („Monografie z Dziejów Oświaty", t. XLI).

УСТАВЫ ИМПЕРАТОРСКИХ МОСКОВСКОГО, ХАРЬКОВСКОГО

И КАЗАНСКОГО УНИВЕРСИТЕТОВ 5 НОЯБРЯ 1804 ГОДА

1864: Сборник постановление по Министерству народного просвещения. 18021825. Т. 1. Стб. 275-279, 283-285, 287-290. СПб.: тип. Имп. Академии Наук.

\section{SCIENTIFIC DEGREES IN IMPERIAL RUSSIA}

\begin{abstract}
Numerous Polish scientists were conferred with scientific degrees in Imperial Russia. It is therefore useful to known what kind of hierarchy these degrees followed.

Keywords: hierarchy of scientific degrees: student, graduated student, candidate of the university, PhD, Dr. Sci.
\end{abstract}

